Tjalling C. Koopmans Research Institute Tplligh Aoopman

Discussion Paper Series nr: 11-11

\title{
Investment risk taking by institutional investors
}

Janko Gorter

Jacob Bikker 


\section{Tjalling C. Koopmans Research Institute \\ Utrecht School of Economics \\ Utrecht University}

Janskerkhof 12

3512 BL Utrecht

The Netherlands

telephone +31302539800

fax +31302537373

website www.koopmansinstitute.uu.nl

The Tjalling C. Koopmans Institute is the research institute and research school of Utrecht School of Economics.

It was founded in 2003, and named after Professor Tjalling C. Koopmans, Dutch-born Nobel Prize laureate in economics of 1975.

In the discussion papers series the Koopmans Institute publishes results of ongoing research for early dissemination of research results, and to enhance discussion with colleagues.

Please send any comments and suggestions on the Koopmans institute, or this series to J.M.vanDort@uu.nl

ontwerp voorblad: WRIK Utrecht

\section{How to reach the authors}

Please direct all correspondence to the first author.

Janko Gorter*

Jacob Bikker*^

* De Nederlandsche Bank (DNB)

Supervisory Policy Division, Strategy Department

P.O. Box 98

1000 AB Amsterdam

the Netherlands

e-mail: J.K.Gorter@dnb.nl

J.A.Bikker@dnb.nl

$\sim$ the Institute for Economics, Econometrics and Finance

University of Groningen

P.O. Box 800

NL-9700 AV Groningen

the Netherlands

^Utrecht University

Utrecht School of Economics

Janskerkhof 12

3512 BL Utrecht

The Netherlands. 
Utrecht School of Economics

Tjalling C. Koopmans Research Institute

Discussion Paper Series 11-11

\title{
Investment risk taking by institutional investors
}

\author{
Janko Gorter ${ }^{\mathrm{ab}}$ \\ Jacob Bikkerac

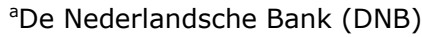 \\ the Netherlands \\ bthe Institute for Economics, Econometrics and Finance \\ University of Groningen \\ 'Utrecht School of Economics \\ Utrecht University
}

May 2011

\begin{abstract}
This paper is the first that formally compares investment risk taking by pension funds and insurance firms. Using a unique and extended dataset that covers the volatile investment period 1995-2009, we find that, in the Netherlands, insurers take substantially less investment risk than pension funds, even though a market risk capital charge for insurers is yet absent. This result can be explained from financial distress costs, which only insurers face. We also find that institutional investors' risk taking is determined by their risk bearing capacity, where this risk bearing capacity depends on capital, size, reinsurance, underwriting risk and human and financial wealth per pension plan participant. Finally, and in line with the ownership structure hypothesis, stock insurers are found to take significantly more investment risk than mutual insurers.
\end{abstract}

Keywords: Portfolio Choice, Insurance Companies, Pension Funds, Ownership Structure

JEL classification: G11; G22; G23; G32

\section{Acknowledgements}

The authors are grateful to Dirk Broeders, Paul Cavelaars, and the participants of the DNB research seminar of 14 October 2010 for valuable comments and suggestions. We thank Jack Bekooij for his excellent research assistance. The views expressed in this paper are personal and do not necessarily reflect those of DNB. 


\section{Introduction}

Investment behaviour of pension funds and insurance firms, particularly their risk return preferences, is of great importance. While more investment risk typically results in higher expected returns, it also tends to increase their asset-liability mismatch, thereby endangering future pension and insurance benefits. Recent crises in the financial markets have made the potential adverse consequences of institutional investment risk taking crystal clear. Indeed, the financial positions of pension funds all over the world have been eroded and both actual and future benefit pay-outs have been reduced. Buffers of insurance firms have also been affected, yet less materially so. The question then arises why some institutional investors take more investment risk than others.

Against this background, this paper investigates investment risk taking by Dutch pension funds and insurance firms over the fifteen year period 1995-2009. Our dataset covers defined benefit pension funds, life insurers and non-life insurers that, in 2009, collectively manage over $€ 1$ trillion in assets, which is almost twice the Dutch gross domestic product (GDP). These assets cover claims of pension plan participants and insurance policyholders. Note that Dutch institutional investors are, in principle, free to choose their desired risk return trade-off, and allocate their assets accordingly. In a study of the regulation of institutional investors in the major OECD countries, Davis (2002) reports that only the United Kingdom and the Netherlands do not impose quantitative restrictions on equity holdings for life insurers.

While there are several empirical papers on investment policies of pension funds (e.g. Lucas and Zeldes 2009; Rauh 2009; Bikker et al. 2010, 2011), this paper is the first that formally compares pension funds' investment policies with those of insurance firms. ${ }^{1}$ The key difference between insurers and pension funds is that the former face financial distress costs, while the latter are technically immune to default. Consequently, pension funds are expected to take more investment risk on board and to be less responsive to changes in their buffer capacity. A related issue is the governance status or organizational form of insurers: stock insurers may have a different risk return trade-off than mutual insurers. Indeed, the ownership structure hypothesis posits that stock insurers have more incentives to take risk than mutual insurers (Lee, Mayers and Smith 1997).

A natural and often-used measure for investment risk taking is the equity allocation, i.e. the percentage of equities in the investment portfolio (see, for instance, Lee et al.1997). Equity investments expose liability-driven investors to considerable income and balance sheet volatility. We examine equity

\footnotetext{
${ }^{1}$ Note that De Haan and Kakes (2010b) also investigate Dutch pension funds and insurance firms, yet these authors focus strictly on feedback trading, i.e. trading on past returns, while we investigate the broader investment risk taking.
} 
allocations both across investors and over time. In the cross-sectional analysis we focus on differences in the level of risk taking across institutions. In the time-series analysis, we examine how trading behaviour responds to past returns, that is, we examine feedback trading. While there is a sizeable literature on feedback trading, ${ }^{2}$ the micro-prudential risk implications of such behaviour have typically been passed over. It can easily be shown, however, that if equity prices follow a random walk, buying equities when equities are down (i.e. negative feedback trading, or rebalancing) is risky, where risk is defined as the probability of loosing the entire capital buffer. Rebalancing would be rewarding if equity prices were mean reverting, but empirical evidence points to annual mean reversion of at most 5\%, and highly volatile at that (Balvers et al. 2000; Spierdijk et al. 2010). Under the same definition, positive feedback trading can also be risky, that is, in upward markets, while it would reduce returns under mean reversion. Hence, feedback trading provides interesting insights into investors' risk taking over time.

The set-up of this paper is as follows. The next section presents further background to and a literature review about the risk taking behaviour of institutional investors and introduces testable hypotheses. Section 3 explains the used methodologies, describes the dataset and provides summary statistics and information about developments over time. Section 4 shows empirical results, both for the comparison of risk taking across types of institutional investors and for the comparison of investment risk behaviour over time. The last section concludes.

\section{Hypotheses}

This paper considers institutional investor risk taking. Below we describe our hypotheses about the relationship between risk bearing capacity and risk taking incentives on the one hand and investment risk taking on the other.

\subsection{Risk-bearing capacity}

Theory provides two competing hypotheses about the relationship between risk bearing capacity and risk taking. The first is the risk -shifting hypothesis, which argues that managers of financially distressed firms have an incentive to increase the volatility of the firm's assets (Jensen and Meckling 1976). The second is the risk management hypothesis, which stresses that bankruptcy risk (Smith and Stulz 1985) and the inability to accept profitable future investment projects (Mayers and Smith 1987) provide an incentive to manage bankruptcy risk. Given that Dutch insurers generally hold capital levels well in excess of the regulatory requirements (De Haan and Kakes 2010) and given Rauh's (2009) finding that risk management incentives dominate risk shifting incentives for US pension plans,

\footnotetext{
${ }^{2}$ See Badrinath and Wahal (2002) for a relatively recent literature overview.
} 
we expect, on average, a positive relationship between risk bearing capacity and investment risk taking.

H1: $\quad$ Investors with more risk bearing capacity take more investment risk, and vice versa.

This paper uses several empirical measures of investor's risk bearing capacity. The first is the capital ratio, which is an important risk factor that provides a direct insight into risk bearing capacity. ${ }^{3}$ With more capital, an institution can shoulder riskier asset portfolios and/or provide safer returns to its stakeholders (Gatzert and Schmeiser 2008). There are, however, costs involved in holding capital (Merton and Perold 1998). Consequently, institutions may be pushed by their stakeholders to use their capital efficiently. This means that in practice, excess capital is likely to be either paid out or to be used to take on additional risk. Consequently, we expect institutions with more capital to take more investment risk, and vice versa.

\section{Hla: Institutional investors with more capital take more investment risk, and vice versa.}

Another risk factor is size. Larger firms generally have more diversification benefits, on both the asset and the liability side of their balance sheets. Diversification benefits can be used to hold a riskier investment portfolio. Though in principle, smaller insurers and pension funds can achieve more risk diversification on their liabilities through reinsurance, in practice, reinsurance is costly due to frictional costs. Larger firms also benefit from scale economies, in being able to set up a more sophisticated risk management organization. Paradoxically, more intensive risk management often leads to more risk taking, as it allows financial institutions to measure their risks more accurately and deploy their scarce capital in the supposedly most efficient way. Large firms may also suffer from overconfidence when they put too much trust in (self-developed) theories and models. Hence, we expect larger firms to take more investment risk.

\section{Hlb: Larger institutional investors take more investment risk, and vice versa.}

The insurance industry consists of various lines of business with diverging risk profiles. We anticipate that in more volatile lines of business, insurers are less eager to take investment risk. An interesting finding from the Solvency II calibration study QIS4 is that underwriting risk is typically larger for

\footnotetext{
${ }^{3}$ In this paper, the capital ratio is an important proxy of an investor's risk bearing capacity. The capital ratio is defined as net asset value (i.e. assets minus liabilities) to total assets. While common in banking, the capital ratio is not the typical solvency indicator in the insurance and pensions industry. In the insurance industry, solvency conditions are usually presented in terms of the solvency ratio. The solvency ratio equals the actual solvency margin divided by the required solvency margin. In the context of pension funds, solvency conditions are typically presented in terms of the funding ratio, which is the ratio of total assets to total liabilities. For ease of comparison, however, we use capital ratios for both insurers and pension funds.
} 
non-life than for life insurers (CEIOPS 2008). Consequently, life insurers can allocate more risk bearing (that is: unused) capital to market risk. In that context, it is important to differentiate between traditional life insurance, where the insurer bears the investment risk, and unit-linked life insurance, where the investment risk is borne by the policyholders. Hence, given a certain capital ratio, life insurers selling predominantly unit-linked policies, that is, life insurers with unit-linked reserves that comprise more than $50 \%$ of the total technical reserves, can afford to take more investment risk, as part of their balance sheet is far less risky. This is indeed recognized by Dutch regulation, which puts a lower capital charge on unit-linked technical provisions (De Haan and Kakes 2010).

Within non-life insurance, five lines of business are distinguished: (1) accident and health, (2) motor, (3) marine, transport and aviation, (4) fire and other property risk, and (5) miscellaneous insurance. Miscellaneous insurance includes a wide variety of insurance products such as travel insurance, legal expenses insurance and credit insurance. Some of these lines are more volatile than others. An oftenused measure to capture non-life underwriting risk is the standard deviation of the loss ratio (e.g., Meyers 1989; Lamm-Tenant and Starks 1993; Guo and Winter 1997). The loss ratio is the ratio of losses incurred to premiums earned and is an often-used measure for underwriting profitability. Table 1 shows percentiles of the distribution of this risk measure for Dutch non-life insurers, both on the line of business and the firm level (based on our dataset, described in Section 3.2). The figures show that motor insurance tends to be a relatively stable line of business in the non-life insurance industry (one third less risky than the average), whilst the category marine, transport and aviation insurance, by contrast, is more than twice as volatile as the reference category motor insurance. In the analyses, we account for differences between the lines of business by including line of business dummies (the dummy for motor insurance is left out and this category therewith acts as the reference group).

Table 1. Standard deviation of the loss ratio, calculated per firm (non-life insurers, 1995-2009)

\begin{tabular}{lcccc}
\hline & $N$ & \multicolumn{3}{c}{ Percentiles } \\
\cline { 3 - 5 } & & $P_{75}$ & $P_{50}$ & $P_{25}$ \\
\hline Line of business level & & & & \\
Accident and health & 107 & 0.21 & 0.12 & 0.07 \\
Motor & 62 & 0.16 & 0.08 & 0.05 \\
Marine, transport and aviation & 54 & 0.49 & 0.18 & 0.13 \\
Fire and other property risk & 126 & 0.26 & 0.15 & 0.09 \\
Miscellaneous insurance & 89 & 0.19 & 0.11 & 0.06 \\
Firm level & 199 & 0.19 & 0.12 & 0.07 \\
\hline
\end{tabular}

Note: standard deviations have been calculated for non-life insurers with 8 or more consecutive years of data.

For insurance firms, reinsurance and group affiliation are also potential determinants of investment behaviour. Insurers that cede more business to reinsurers have less underwriting risk and can thus allocate more capital to investment risk. If group control is imperfect, i.e. there is considerable 
independence on the part of affiliated firms, as Bikker and Gorter (2011) suggest, then affiliated firms have an incentive to take more risk.

H1c: Insurers with more underwriting risk take less investment risk, and vice versa.

For pension funds, we hypothesize that the share of active participants positively influences the degree of risk taking (Rauh 2009; Bikker et al. 2011). This variable largely determines the effectiveness of raising premium contributions to stave off underfunding.

HId: Pension funds with more active participants take more investment risk, and vice versa.

Another pension-fund-specific variable we consider is total pension wealth per plan participant. At the end of the day, pension funds invest for private persons, who, on average, invest more in equity the larger their savings are (Cohn et al.1975).

Hle: Pension funds with wealthier plan participants take more investment risk, and vice versa.

\subsection{Pension funds versus insurers}

We expect pension funds to take more investment risk than insurance firms. Pension funds are trusts and when assets fall below liabilities, a fund does not go bankrupt, employees are not laid off and nonmarketable assets are not lost. Indeed, in the US, the UK and, more recently, the Netherlands, several defined benefit pension funds have become underfunded yet do not automatically cease operations. An important reason why Dutch funds can recover from a negative capital position is that employees are obliged to take part in the pertaining pension scheme. This is not the case for insurers, which are more likely to lose policyholders when solvency capital runs low. In fact, empirical evidence shows that insurers do indeed face financial distress costs. Sommer (1996) and Cummins and Danzon (1997) show that insurance is priced as risky debt, and that insurance prices are inversely related to insurer default probabilities.

Another, related reason why pension funds are expected to take more investment risk concerns regulation. When an insurer's capital ratio falls below the regulatory minimum, the prudential supervisor, which in the Netherlands is De Nederlandsche Bank (DNB), assumes control over the insurer. Management is then replaced and gambling for resurrection behaviour on their part is prevented. As a result consumers are protected against extensive losses and owners and management have an incentive to stay away from the regulatory minimum. Indeed, De Haan and Kakes (2010) show Dutch insurers generally hold far more capital than is required by regulation. Regulation is different for pension funds. When a pension fund falls below the minimal capital ratio of $5 \%$, it is 
normally given three years to recover. This may be done by (a combination of) reducing or eliminating indexation, increasing contributions, receiving a subordinate loan or by renegotiating the unconditional rights between the employer and trade unions. In exceptional circumstances, the government can allow a longer recovery period. This happened in 2009, in fact, when the government extented the recovery period to five years. Hence, pension regulation is less strict.

In light of abovementioned differences between pension funds and insurance firms, we hypothesize the following:

\section{H2: $\quad$ Pension funds take more investment risk than insurers.}

H3: $\quad$ The relationship between capital and investment risk taking is more pronounced for insurers than for pension funds.

We anticipate $H 2$ and $H 3$ to hold true, despite the relative risk insensitivity of the current insurance solvency requirements. Though underwriting risk is to some extent reflected in the solvency requirements, investment risk is not (De Haan and Kakes 2010). ${ }^{4}$ By contrast, pension funds regulation in the Netherlands has been risk based since 2007, when the Financial Assessment Framework (in Dutch: Financieel Toetsingskader, FTK) became effective (Bikker and Vlaar 2007). According to this risk based regulatory framework, pension funds are required to hold a higher risk margin for risky investments such as equities. In principle available capital should be sufficient to maintain a less than 2.5 per cent probability of insolvency over a one-year horizon. For an average pension fund, this implies a target capital ratio of around 30 percent. Since pension funds do not have to de-risk when buffers run low, we do not expect them to be more risk sensitive in their investment behaviour than insurers. Note that the FTK did not only make supervision more risk based, it also changed the way pension liabilities are calculated. Until end-2006, pension liabilities were calculated on the basis of a fixed actuarial interest rate of at most 4 per cent (a figure that had not changed since 1969), which was considered a conservative estimate of the expected long-run real return on the asset portfolio. With the introduction of the FTK, the fixed actuarial interest rate to calculate liabilities was replaced by the (nominal) market rate. This was an important change that had an immediate impact on capital ratios, or - in the pension domain - funding ratios.

\subsection{Stock versus mutual insurers}

There are many hypotheses about organizational form and the insurance industry is eminently suited for testing these hypotheses. The stock and mutual organizational form are present in insurance

\footnotetext{
${ }^{4}$ This will change in 2012, when the European Union will implement a new, risk based regulatory approach for insurance companies, called 'Solvency II.'
} 
markets around the world (Swiss Re, 1999). In the Dutch insurance market, too, stocks and mutuals have coexisted for many decades.

This paper focuses on the risk implications of organizational form. Lamm-Tenant and Starks (1993) investigate this issue for the US insurance market, yet they look at underwriting rather than investment risk. They find that stocks bear significantly more underwriting risk than mutuals. Lee et al. (1997) examine investment risk taking across stocks and mutuals. They propose the ownership-structure hypothesis, which predicts that stock firms have stronger risk taking incentives than mutuals. The underlying logic here is that stock owners are able to increase the value of their claims by increasing portfolio risk - because of limited liability - while mutual owners typically are not. Mutual ownership claims are held by policyholders and are principally inalienable. Consequently, in case of mutual firms, the benefits from risk shifting are low and more diffuse (Esty 1997). Stock insurers' ownership claims, on the other hand, are held by specialized residual claimants whose claims are alienable. This alienability facilitates stock owners to offer management pay-for-performance compensation packages, including equity holdings en equity options, therewith encouraging them as well to take asset risk (Mayers and Smith 1992). ${ }^{5}$

Lee et al. (1997) study changes in U.S. insurers' asset portfolios after guaranty fund enactment. They find that only stock insurers shifted to riskier assets following fund enactment, providing support for the ownership-structure hypothesis. Since Lee et al. (1997) study asset risk taking across stocks and mutuals following an exogenous event, they naturally control for differences in underwriting risk between stocks and mutuals. Controlling for underwriting risk is important, as stock insurers are both predicted and found to be associated with riskier insurance business (e.g. Fama and Jensen 1983; Smith and Stutzer 1990; Mayers and Smith 1992, 1994; Lamm-Tenant and Starks 1993). Hence, we expect that, corrected for the relevant risk factors, summed up in Section 2.1, stocks take more investment risk than mutuals.

H4: $\quad$ Stock insurers generally take more investment risk than mutual insurers.

\section{Methodology and data}

This section explains how we test our hypotheses about financial institutions' investment risk taking. The modelling and estimation methodologies are discussed first, after which the data are presented.

\footnotetext{
${ }^{5}$ Though in principle mutual insurers could mimic such compensation packages, to the best of our knowledge this does not happen in practice.
} 


\subsection{Methodology}

This paper investigates investment risk taking from two angles. We start by investigating equity allocations across investors and disregard market developments over time by including year dummies. Subsequently, we turn our focus to market developments and analyze how the various investor types react to these developments over time. Since prudent investors are more likely to survive than aggressive investors, especially during our sample period with turmoil years, one could argue that survivorship bias is likely to drive our results. As our dataset includes institutional investors that have ceased operations, we can compare balanced and unbalanced estimation results to gauge the survivorship bias.

\subsubsection{Equity allocations across investors}

The first part of our analysis, on equity allocations across investors, controls for yearly fluctuations and investigates how equity allocations relate to risk bearing capacity and risk taking incentives. Equity investments typically expose liability-driven investors to considerable income and balance sheet volatility and have therefore been frequently used as measures of risk taking. Lee et al. (1997), Cummins and Nini (2002) and De Haan and Kakes (2010) use this measure for insurers, while Lucas and Zeldes (2009) and Bikker et al. (2011) use this measure in a study of, respectively, US and Dutch pension funds. To the best of our knowledge, this paper is the first that compares equity allocations of insurance firms and pension funds.

Our empirical specification reads as follows:

$$
\begin{aligned}
W_{i, t}= & \alpha_{0}+\alpha_{1} C R_{i, t-1}+\alpha_{2} \ln \operatorname{SIZE}_{i, t-1} \\
& +D_{i}^{I}\left[\alpha_{3}+\alpha_{4} C R_{i, t-1}+\alpha_{5} \ln \operatorname{SIZE}_{i, t-1}+\alpha_{6} \operatorname{STOCK}_{i}+\sum_{q=0}^{5} \alpha_{7+q} L O B_{i, q, t}+\alpha_{13} G_{i, t}+\alpha_{14} R R_{i, t-1}\right] \\
& +D_{i}^{P F}\left[\alpha_{15} S A_{i, t}+\alpha_{16} \ln W P_{i, t-1}\right]+\sum_{t=1}^{T-2} \alpha_{16+t} Y D_{t}+\varepsilon_{i, t},
\end{aligned}
$$

where $W_{i, t}$ is the equity allocation of investor $i$ in year $t$, written as a linear function $f$ of coefficient vector $\alpha$ and a set of explanatory variables. Dummy variables $D_{i}^{I}$ (1 for insurers) and $D_{i}^{P F}$ (1 for pension funds) allow for differences in the coefficients between insurers and pension funds. $C R_{i, t-1}$ and $\ln S I Z E_{i, t-1}$ stand for, respectively, lagged capital ratio and lagged firm size (measured by total investment portfolio size) in logarithms, and are available for both insurance firms and pension funds. $\operatorname{STOCK}_{i}$ is a dummy variable which takes the value 1 for stock insurers and 0 otherwise, and captures equity allocation differences between stocks and mutuals. $L O B_{i, q, t}$ for $q=0$ to $q=5$, are insurance line- 
of-business dummies for six of the seven lines, ${ }^{6}$ which take the value 1 if a firm is predominantly active in the respective line. ${ }^{7}$ The relatively stable non-life insurance line of business motor insurance acts as the reference group. Dummy variable $G_{i, t}$ ( 1 for firms affiliated to a group) is included to control for group affiliation. $R R_{i, t-1}$ is the reinsurance ratio lagged, i.e. last year's premiums ceded as a percentage of last year's total premiums. This reinsurance proxy is used by, among others, Cummins and Nini (2002) and De Haan and Kakes (2010). $S A_{i, t}$ and $\ln W P_{i, t-1}$ are pension-fund-specific variables, which measure, respectively, the share of active participants and lagged total assets per participant (in logarithms). Because we use lagged variables, $T-2$ (and not $T$-1) year dummies $Y D_{t}$ are included to account for equity market developments, where $T$ is the number of sample years. Finally, the error term is represented by $\varepsilon_{i, t}$.

\subsubsection{Equity allocations over time}

The second part of our analysis, on equity allocations over time, touches upon the issue of feedback trading. There is a sizeable empirical literature on feedback trading by institutions. While all available studies find that past equity returns significantly influence today's trading behaviour, evidence on the sign of such feedback trading is mixed. Grinblatt et al. (1995) find positive feedback trading for US institutions, yet Lakonishok et al. (1992) and Gompers and Metrick (2001) do not observe significant positive feedback trading. The question then rises, why some institutions engage in positive feedback trading and others do not. We argue that risk bearing capacity probably plays an important role.

Available studies on Dutch pension funds report negative feedback trading (Kakes 2008; Bikker et al. 2010). Negative feedback trading, or rebalancing, is often motivated by mean reversion in equity prices. Under mean reversion, an institution can achieve higher returns by buying equities when markets are down and selling equities when markets are up. However, since the equity cycle length can be long and volatile (Spierdijk et al. 2010) and the degree of mean reversion is likely to be small and uncertain (see Pástor and Stambaugh 2009), rebalancing can be a particularly risky trading strategy. Under marked-to-market accounting, falling equity prices lead to lower risk bearing capacity. Buying equities when capital is low is risky business and only possible for unconstrained or loosely constrained investors. Constrained investors, on the other hand, can be forced to liquidate their equity

\footnotetext{
${ }^{6}$ The seven lines-of-business dummies consist of five non-life insurance categories (accident and health, motor, marine, transport and aviation, fire and other property risk, and miscellaneous insurance) and two life insurance lines of business, namely unit-linked life and traditional life.

${ }^{7}$ Note that non-life insurers are not permitted to write life insurance policies, and, vice versa, life insurers are not permitted to write non-life insurance policies. That being so, insurance holding companies are allow to have both life and non-life subsidiaries. A non-life-insurer is predominantly active in a specific non-life insurance line of business when more than fifty percent of its premium income comes from this line. As our dataset only discerns two life insurance lines of business, all life insurers are either characterized as a traditional life insurer or as a unit-linked life insurer. We distinguish traditional and unit-linked life insurers by technical reserves. A life insurer is predominantly active in traditional life when more than fifty percent of its technical reserves are traditional life reserves.
} 
holdings just when everyone else is trying to shed risk, a phenomenon known as fire sales (Shleifer and Vishny 1992). ${ }^{8}$ The reverse happens in upturns. Rising equity markets increase investors' willingness and ability to take risk (Black 1988). While such positive-feedback trading is understandable from a microprudential perspective, it can lead to procyclicality and to booms and busts in financial markets. Using quarterly data over the period 1999-2005, De Haan and Kakes (2011) find that Dutch pension funds and insurance firms are, on average, negative-feedback traders. Other than De Haan and Kakes (2011), who use survey data that are collected for statistical purposes (balance-of-payments statistics), this study uses regulatory data with an annual frequency. Main advantages are better coverage (all regulated investors are included), a longer time-span (1995-2009), including the recent financial crisis, and a breakdown of traditional life and unit-linked life investments. The latter is important, as the market risk in unit-linked investment portfolios is borne by policyholders and not by the respective life insurers (see Section 2.1).

Let equity allocation $W_{i, t}$ be defined as $W_{i, t}=E_{i, t} / T I_{i, t}$, with equity and total investments represented by $E_{i, t}$ and $T I_{i, t}$, respectively. $W_{i, t}$ can, by definition, be decomposed into three factors:

$$
W_{i, t}=\frac{E_{i, t}}{T I_{i, t}}=\frac{E_{i, t}^{R E V}}{T I_{i, t}}+\frac{E_{i, t}^{N C F}}{T I_{t}}+W_{i, t-1} \frac{T I_{i, t-1}}{T I_{i, t}}
$$

where $E_{i, t}^{R E V}$ is the euro amount of equity gains or losses. $E_{i, t}^{N C F}$ is the euro amount of net purchases or sales and $T I_{i, t-1} / T I_{i, t}$ is the inverse of portfolio growth. When non-equity assets grow and the value of equity holdings remains constant, the equity allocation drops as a result of positive portfolio growth.

Obviously, the three factors in Equation (2) all have a one-to-one effect on the equity allocation. What we are interested in, however, is whether these factors are generally reinforcing or counterbalancing. To investigate this, we introduce the following basic model:

$$
W_{i, t}-W_{i, t-1} \frac{T I_{i, t-1}}{T I_{i, t}}=\frac{\Delta E_{i, t}}{T I_{i, t}}=\beta_{0}+\beta_{1} \frac{E_{i, t}^{R E V}}{T I_{i, t}}+\varepsilon_{i, t},
$$

with $\Delta E_{i, t}$ representing absolute equity portfolio growth of investor $i$ in year $t$. Comparing Equations (2) and (3), notice that we have dropped trading factor $E_{i, t}^{N C F} / T I_{i, t}$. Doing so, we avoid the endogeneity problem posed by this variable. While net equity transactions have a direct effect on the

\footnotetext{
${ }^{8}$ Brunnermeier (2009), among others, argues that fire sales have amplified the recent mortgage crisis into a severe financial crisis.
} 
size of the equity portfolio, the reserve may also happen: changes in the equity portfolio may incite investors to change their net cash flow to equities. Estimating Equation (3) by OLS gives us an estimate $b_{1}$ for $\beta_{1}$ with expected value $E\left[b_{1}\right]=1+\operatorname{Cov}($ Revaluation,Trading $) / \operatorname{Var}($ Trading $)$. Hence, with $b_{1}>1\left(b_{1}<1\right)$, the sample correlation between market returns and equity net purchases is positive (negative), suggesting positive (negative) feedback trading behaviour.

In order to allow for asymmetric feedback trading or rebalancing behaviour, that is different trading behaviour in bear and bull markets, we generalize Equation (3) to

$$
\frac{\Delta E_{i, t}}{T I_{i, t}}=\beta_{0}+D_{i, t}^{P O S} \beta_{1}^{P O S} \frac{E_{i, t}^{R E V}}{T I_{i, t}}+D_{i, t}^{N E G} \beta_{1}^{N E G} \frac{E_{i, t}^{R E V}}{T I_{i, t}}+\varepsilon_{i, t}
$$

where $D_{i, t}^{P O S}$ and $D_{i, t}^{N E G}$ are investor-specific dummy variables that take the value 1 if equity returns in year $t$ are positive and negative, respectively, and 0 otherwise. Further, we allow for different behaviour for the various institutional investors we consider, that is pension funds, stock insurers and mutual insurers, by multiplying the $\beta$ coefficients in Equation (4) with sector dummies (or by estimating this equation separately for both groups). In this way we obtain sector-specific insights with respect to our hypotheses from a trading perspective.

\subsection{Data}

This study draws on a comprehensive dataset of annual observations, covering all regulated pension funds and insurance firms in the Netherlands. ${ }^{9}$ It covers pension funds, life insurers and non-life insurers over the 1995-2009 period. ${ }^{10}$ Note that for life insurers, we only include investments for their own account, so that unit-linked investments are excluded from the equity allocations used in estimations of Equation (1). ${ }^{11}$ After sanitization, the dataset contains 12,866 institution-year observations. ${ }^{12}$ Note that for pension funds, transaction and revaluation data are only available from 2000 and onwards. This holds also for strategic equity allocation figures. In our analysis the focus is

\footnotetext{
${ }^{9}$ This dataset does not include funeral insurers and tiny mutual non-life insurers exempted from supervision.

${ }^{10}$ Because of the long time span of our dataset, one could worry about structural breaks in de data. There have indeed been regulatory and accounting changes during our sample period. Fortunately, the timing of these breaks is known exactly. From 2006 and onwards, with the enactment of the Dutch Health Insurance Act, the former national health insurance funds enter our dataset as non-life insurers, active in the health and accident line of business. For pension funds, there has been a regulatory regime change in 2007, as explained in Section 2.1. Hence, the period 1995-2005 constitutes a stable regime. We use this period to test the robustness of our full sample results.

${ }^{11}$ Though we exclude unit-linked investments, we account for unit-linked activities by including a dummy variable. Footnote 8 explains in detail how the line-of-business dummies are calculated.

12 The raw dataset contains 18,416 institution-year observations. We have excluded defined contribution (DC) pension funds (573 observations), as they would confound our analysis. In DC funds, the investment risk is typically borne by the pension fund participants and not by the pension fund itself. We have also excluded observations that have zero or negative total assets, negative equity allocation, equity allocation $>100 \%$, capital ratio $>1$ or capital ratio $<-0.3$. Note that our data source does not distinct between zeroes and missing values.
} 
on individual entities regulated by the Dutch supervisory authorities, because, in contrast to banking supervision, insurance supervision is non-consolidated. As most insurers are group affiliated, however, we control for group affiliation in our regression analyses. ${ }^{13}$

Table 2 summarizes the data. While life insurers are larger, on average, than pension funds, in terms of balance sheet size, the latter invest relatively more in equities. ${ }^{14}$ On average, pension funds invest even more in equities than their surplus or buffer. This is generally not the case for life insurers and certainly not for non-life insurers. Non-life insurers have relatively large capital buffers, which apparently are not used to take on additional investment risk. As mentioned in the previous section, underwriting risk is their dominant risk category. The average wealth per defined benefit pension plan participant is about $€ 120,000$, which is more than twice the median value. Boards of directors tend to have their own pension schemes and such schemes tilts up considerably the average pension fund wealth. Notice that non-life insurers are relatively small investors compared to life insurers and pension funds. This is a direct result of the short-term nature of non-life insurance policies. The organizational form dummy shows that mutuals are most prevalent in the non-life industry. The number of non-life insurers is almost three times that of life insurers, while about $45 \%$ of the non-life insurers is mutual-owned.

Table 2. Full sample summary statistics, in 2009 prices (1995-2009)

\begin{tabular}{|c|c|c|c|c|c|c|}
\hline & \multicolumn{2}{|c|}{ Pension funds } & \multicolumn{2}{|c|}{ Life insurers } & \multicolumn{2}{|c|}{ Non-life insurers } \\
\hline & mean & median & mean & median & mean & median \\
\hline Equity holdings (in $€$ millions) & 371 & 15 & 365 & 12 & 28 & 1 \\
\hline Total investments (in $€$ millions) & 953 & 60 & 2204 & 286 & 145 & 15 \\
\hline Equity allocation $(\%)$ & 28 & 28 & 14 & 8 & 16 & 9 \\
\hline Capital ratio $(\%)$ & 10 & 12 & 15 & 9 & 47 & 47 \\
\hline Investments per participant (x $1000 €)$ & 119 & 54 & & & & \\
\hline Number of participants (x 1000) & 26 & 1 & & & & \\
\hline Share of active participants (\%) & 42 & 42 & & & & \\
\hline Reinsurance ratio $(\%)$ & & & 6 & 1 & 24 & 15 \\
\hline Organization form $(1=$ mutual $)$ & & & 0.11 & 0 & 0.45 & 0 \\
\hline Group (1=group affiliation) & & & 0.73 & 1 & 0.65 & 1 \\
\hline \multicolumn{7}{|l|}{ Line-of-business dummies } \\
\hline Traditional life & & & 0.76 & 1 & & \\
\hline Unit-linked & & & 0.24 & 0 & & \\
\hline Accident and health & & & & & 0.29 & 0 \\
\hline Motor & & & & & 0.08 & 0 \\
\hline Fire and other property risk & & & & & 0.34 & 0 \\
\hline Marine, transport and aviation & & & & & 0.05 & 0 \\
\hline Miscellaneous insurance & & & & & 0.08 & 0 \\
\hline Institution-year observations & 8,275 & & 1,218 & & 3,347 & \\
\hline
\end{tabular}

\footnotetext{
${ }^{13}$ As in Bikker and Gorter (2011), we take subsidiaries and not groups as the primary decision-making unit, because subsidiaries in the insurance industry tend to operate highly or even completely independently.

${ }^{14}$ Pension funds world-wide have a higher equity allocation than life insurers (Broeders et al. 2011).
} 
The second part of our analysis investigates how investors' equity allocations change over time. By way of preview, Figure 1 plots the weighted-average equity allocation over our sample period. For pension funds we do not only have actual equity allocations but also strategic asset allocations, as reported to DNB, the prudential supervisor in the Netherlands. ${ }^{15}$ All institutional investors let their equity allocation increase during the late nineties, along with the technology bubble. When the bubble burst, however, investors' behaviour diverged. While insurers let their equity exposure decrease, pension funds maintained equity allocation at a high level close to $40 \%$, in line with their allocation strategy. This points to considerable negative feedback trading by pension funds. Indeed, Bikker et al. (2010) report over a shorter sample period - up to and including 2006 - considerable rebalancing behaviour by Dutch pension funds. Figure 1 shows that during the widespread financial crisis of 20082009 , pension fund were less successful in rebalancing their equity allocation. The weighted average equity allocation dropped by almost 10 percentage points in 2008. Interestingly, the strategic allocation was also adjusted downwards. Comparing life and non-life insurers, we see that the latter generally allocate a larger proportion of their assets to equities. We also see that life insurers were net seller of equities in 2009 , as the equity allocation dropped while equity markets were up that year.

Figure 1. Equity allocations by sector (weighted averages; 1995-2009)

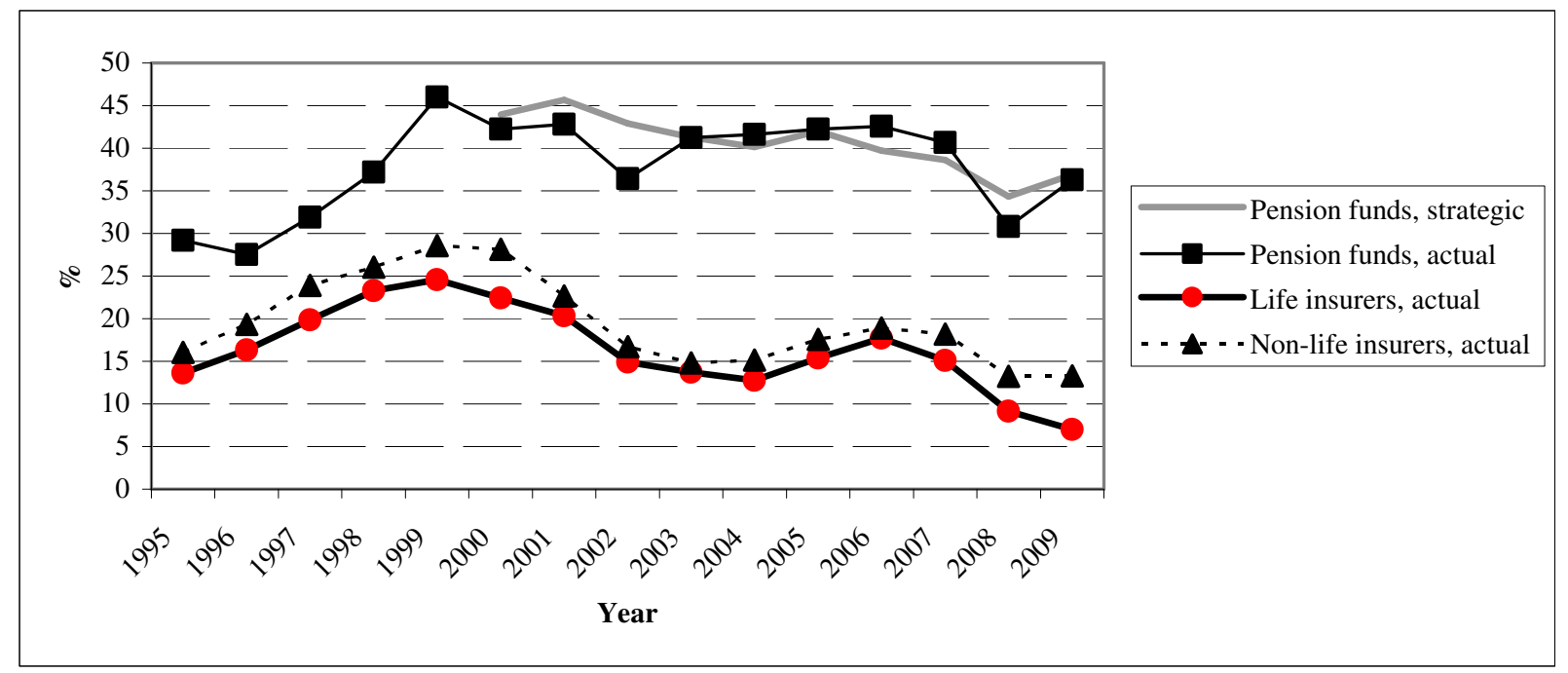

Notes: weighted-average equity allocations are total year-end equity holdings divided by total investments. For life insurers, unit-linked investments have been excluded.

\section{Empirical results}

Investment risk taking has been investigated along two lines. First, we examine equity allocations across investors, disregarding market developments over time. Second, we analyse how the various investor types react to market developments over time.

\footnotetext{
${ }^{15}$ Note that for pension funds, the weighted-average equity allocation is considerably higher than the average equity allocation (as shown in Table 2), suggesting support for hypothesis Hla (risk taking increases in size).
} 


\subsection{Equity allocations across investors}

The results of OLS estimations of Equation (1) are given in Table $3 .{ }^{16}$ Column I shows full sample results, while Column II presents outcomes for the shorter sample period 1995-2005. The shorter sample period is more stable in terms of regulatory and accounting regimes. In 2006 the former national health insurance funds were privatized and in 2007 risk based regulation of pension funds was introduced. Column III provides balanced-panel results for the 1995-2005 period. Differences between the balanced and unbalanced panel results may give an indication of the magnitude of survivorship bias. Of course, the varying set of observations may also have an effect on the parameter estimates. Note that the degree-of-fit is highest for the most homogeneous sample: the balanced 1995-2005 dataset.

Table 3. OLS estimation results of the equity allocation model

\begin{tabular}{|c|c|c|c|c|}
\hline Variable & $\begin{array}{l}\text { Coeffi } \\
\text {-cient }\end{array}$ & $\begin{array}{c}\text { 1995-2009 } \\
\text { unbalanced }\end{array}$ & $\begin{array}{c}\text { 1995-2005 } \\
\text { unbalanced }\end{array}$ & $\begin{array}{c}1995-2005 \\
\text { balanced }\end{array}$ \\
\hline Column & & $\bar{I}$ & II & III \\
\hline Constant & $\overline{\alpha_{0}}$ & $* * 23.11$ & $* * 30.11$ & $* * 25.78$ \\
\hline Capital ratio (lagged) & $\alpha_{1}$ & $* * 6.63$ & $* * 7.93$ & $* * 6.40$ \\
\hline Portfolio size (logarithm, lagged) & $\alpha_{2}$ & $* * 2.28$ & $* * 2.51$ & $* * 2.19$ \\
\hline$D^{I}$ & $\alpha_{3}$ & $* *_{-} 12.76$ & $* *_{-} 14.15$ & $*_{-}-18.01$ \\
\hline$D^{I} \bullet$ Capital ratio (lagged) & $\alpha_{4}$ & $* * 15.57$ & $* * 18.55$ & $* * 23.98$ \\
\hline$D^{I} \bullet$ Portfolio size (logarithm, lagged) & $\alpha_{5}$ & $* *_{-} 1.63$ & $* *-1.40$ & $*_{-}-1.74$ \\
\hline$D^{I} \bullet S T O C K$ & $\alpha_{6}$ & $* * 2.63$ & $* * 3.15$ & $* * 6.09$ \\
\hline$D^{I} \bullet L O B_{\text {health }}$ & $\alpha_{7}$ & -1.27 & -1.90 & -0.64 \\
\hline$D^{I} \bullet L O B_{\text {transport }}$ & $\alpha_{8}$ & $* *_{-} 8.67$ & $* *-6.54$ & -4.80 \\
\hline$D^{I} \bullet L O B_{\text {fire }}$ & $\alpha_{9}$ & $* *-5.62$ & $* *-5.67$ & $* *-5.68$ \\
\hline$D^{I} \bullet L O B_{\text {miscellaneous }}$ & $\alpha_{10}$ & $* *-4.00$ & $* *-6.02$ & $*_{-} *_{-} 6.00$ \\
\hline$D^{I} \bullet L O B_{\text {traditional life }}$ & $\alpha_{11}$ & $*-2.72$ & $*_{-}-2.33$ & -1.35 \\
\hline$D^{I} \bullet L O B_{\text {unit-linked life }}$ & $\alpha_{12}$ & $* * 6.95$ & $* * 7.23$ & $* * 8.94$ \\
\hline$D^{I} \bullet$ Group affiliation & $\alpha_{13}$ & 0.93 & 0.91 & 1.31 \\
\hline$D^{I} \bullet$ Reinsurance ratio (lagged) & $\alpha_{14}$ & $* 0.62$ & $* 0.72$ & $* 0.82$ \\
\hline$D^{P F} \cdot$ Share active participants & $\alpha_{15}$ & $* * 3.19$ & $* * 3.08$ & 1.46 \\
\hline$D^{P F} \bullet$ Assets per participant (logarithm, lagged) & $\alpha_{16}$ & $* * 1.48$ & $* * 1.45$ & $* * 1.83$ \\
\hline Number of observations & & 11,242 & 8,670 & 5,556 \\
\hline $\mathrm{R}^{2}$, adjusted & & 22 & 25 & 29 \\
\hline
\end{tabular}

Notes: * and ** denote significance at, respectively, the 5\% and $1 \%$ level, calculated using Huber-White robust standard errors. The dependent in these regressions is the equity allocation in percentages. $D^{I}$ is a dummy, which is 1 for insurers and 0 for pension funds. $L O B$ are the different line of business dummies, which take the value 1 for insurers that are predominantly active in the respective line, and 0 otherwise. Organizational form dummy STOCK is 1 for stock insurers and 0 otherwise. $D^{P F}$ is a dummy, which is 1 for pension funds and 0 for insurers. Year dummy estimates are not shown. For expositional purposes, all non-dummy variables are in deviation from their sample means.

The capital ratio is highly significant at the $1 \%$ level, irrespective of the sample $\left(\alpha_{1}\right)$. Hence, investors with larger capital buffers take more equity risks, confirming Hla. The relationship between capital and risk taking is significantly more pronounced for insurers than for pension funds $\left(\alpha_{4}\right)$. Hence we

\footnotetext{
${ }^{16}$ As the dependent, i.e. the equity allocation, contains many zeroes, we have also regressed equity allocation on our explanatory variables using Tobit. The results are the same, both quantitatively and qualitatively.
} 
find support for $\mathrm{H} 3$ as the results show that insurers choose their asset allocations in a more risk sensitive manner than pension funds. Portfolio size has a significant and positive effect on investment risk taking. For pension funds the effect is quite strong: when total investments double, the equity allocation rises with more than 2 percentage points $\left(\alpha_{2}\right)$. This result is in line with earlier estimates for pension funds (Bikker et al. 2010, 2011). For insurers, the relationship between portfolio size and risk taking is weaker ( $\alpha_{5}$ is significantly negative), but still significantly positive for the unbalanced samples. Accordingly, we find support for $H 1 b$. An explanation for the weaker relationship for insurers is that large pension funds suffer more from overconfidence than large insurers. Although this is hard to prove scientifically, this explanation would be consistent with our other results. In line with $H 2$ we find that pension funds take significantly more investment risk than insurers, even after correcting for capital and size. The (weighted) sum of the insurer dummy coefficient $\left(\alpha_{3}\right)$ and the interaction coefficients $\alpha_{6}-\alpha_{13}$ is significantly negative ${ }^{17}$, which means that insurers have significantly lower equity allocations than pension funds.

Let us now turn to the hypothesis about underwriting risk and investment risk taking by insurers (HIc). The estimates of $\alpha_{8}-\alpha_{10}$ show that transport, fire and miscellaneous insurers tend to take significantly less investment risk than motor insurers (reference group). Since motor insurers tend to have more stable underwriting results (see Table 1), this finding supports $H 1 c$. The equity allocation of health insurers does not significantly deviate from that of motor insurers $\left(\alpha_{6}\right)$, however. Equity investments of unit-linked life insurers (to be sure: on their own account) are significantly larger than those of motor insurers $\left(\alpha_{11}\right)$. Apparently, where unit-linked investment does not imply risk for insurers, they 'compensate' that by investing more in equities on their own account (supporting Hlc). Note that the reinsurance ratio coefficient also supports $H 1 c$, across all samples $\left(\alpha_{14}\right)$. Insurers that cede more business to reinsurers tend to take significantly more equity risk (at the 5\% level).

Hypotheses $H I d$ and Hle concern pension funds. The estimates of $\alpha_{14}$ indicate that the share of active participants has a significantly positive effect for the two unbalanced samples, but not for the balanced one. One argument is that active participants largely determine the effectiveness of raising premium to stave off underfunding. A second reason is that the life-cycle theory states that active (and younger) participants can take more risk - and, hence, should invest more in equities - than retired ones (Bikker et al. 2011). Once more, risk bearing capacity is the main explanation: active participants can

\footnotetext{
${ }^{17}$ The average equity allocation difference between pension funds and insurance firms is picked up by the insurance dummy. Since the insurance dummy is interacted with other dummy variables (i.e. STOCK, LOB. and $G)$, the equity allocation difference between insurers and pension funds is a weighted sum of the estimated coefficients of $\alpha_{3}$ and coefficients $\alpha_{6}$ - $\alpha_{13}$.
} 
compensate negative returns on investment by extending working hours or delaying retirement. Higher wealth per participant implies a significantly higher equity ratio $\left(\alpha_{15}\right)$, in line with Hle.

Our last hypothesis ( $\mathrm{H} 4)$ is about the role of organizational form in explaining investment risk taking. The results in Table 3 show that, corrected for the relevant risk factor, stock insurers indeed take significantly more investment risk than mutual insurers $\left(\alpha_{5}\right)$.

Table 4 provides an overview of the parameter values and their relationship with the hypotheses considered. Whether we use balanced or unbalanced data, the 1995-2005 or the 1995-2009 period, the estimation results generally support our hypotheses. One minor exception is that we cannot the reject the null hypothesis that health insurers invest as assertively as motor insurers, yet all other parameter estimates are consistent with HIc. Comparing the results across the different samples we note that selection bias does not seem to affect the estimation results. The results have also not been influenced substantially by the recent financial crises, the health insurance reforms, or changes in pension regulation.

Table 4. Overview of the parameter values and their relationship with the hypotheses

\begin{tabular}{|c|c|c|c|c|}
\hline \multirow[t]{2}{*}{ Hypotheses } & \multirow[t]{2}{*}{ Supporting parameters ${ }^{1}$} & \multicolumn{3}{|c|}{ P-values (null: no significant effect) } \\
\hline & & $\begin{array}{c}\text { 1995-2009 } \\
\text { unbalanced }\end{array}$ & $\begin{array}{l}\text { 1995-2005 } \\
\text { unbalanced }\end{array}$ & $\begin{array}{c}1995-2005 \\
\text { balanced }\end{array}$ \\
\hline $\begin{array}{l}\text { Hla: More capital, more investment } \\
\text { risk, and vice versa }\end{array}$ & $\begin{array}{l}\text { Pension funds: } \alpha_{1}>0 \\
\text { Insurance firms: } \alpha_{1}+\alpha_{4}>0\end{array}$ & $\begin{array}{l}0.00 \\
0.00\end{array}$ & $\begin{array}{l}0.00 \\
0.00\end{array}$ & $\begin{array}{l}0.00 \\
0.00\end{array}$ \\
\hline $\begin{array}{l}H 1 b \text { : Larger portfolio size, more } \\
\text { investment risk, and vice versa }\end{array}$ & $\begin{array}{l}\text { Pension funds: } \alpha_{2}>0 \\
\text { Insurance firms: } \alpha_{2}+\alpha_{5}>0\end{array}$ & $\begin{array}{l}0.00 \\
0.00\end{array}$ & $\begin{array}{l}0.00 \\
0.00\end{array}$ & $\begin{array}{l}0.00 \\
0.15\end{array}$ \\
\hline $\begin{array}{l}\text { HIc: More underwriting risk, less } \\
\text { investment risk, and vice versa }{ }^{1}\end{array}$ & $\begin{array}{l}\alpha_{7}<0 \\
\alpha_{8}<0 \\
\alpha_{9}<0 \\
\alpha_{10}<0 \\
\alpha_{12}>0 \\
\alpha_{14}>0\end{array}$ & $\begin{array}{l}0.29 \\
0.00 \\
0.00 \\
0.00 \\
0.00 \\
0.04\end{array}$ & $\begin{array}{l}0.15 \\
0.00 \\
0.00 \\
0.00 \\
0.00 \\
0.02\end{array}$ & $\begin{array}{l}0.69 \\
0.06 \\
0.00 \\
0.00 \\
0.00 \\
0.04\end{array}$ \\
\hline $\begin{array}{l}\text { Hld: More active participants, more } \\
\text { investment risk, and vice versa }\end{array}$ & $\alpha_{15}>0$ & 0.00 & 0.01 & 0.41 \\
\hline $\begin{array}{l}\text { H1e: Wealthier plan participants, more } \\
\text { investment risk, and vice versa }\end{array}$ & $\alpha_{16}>0$ & 0.00 & 0.00 & 0.00 \\
\hline $\begin{array}{l}\text { H2: Pension funds take more } \\
\text { investment risk than insurers }\end{array}$ & $\begin{array}{l}\alpha_{3}+\alpha_{6} \operatorname{mean}(\text { STOCK }) \\
+\sum_{q=0}^{5} \alpha_{7+q} \operatorname{mean}\left(L O B_{q}\right) \\
+\alpha_{13} \operatorname{mean}(G)<0\end{array}$ & 0.00 & 0.00 & 0.00 \\
\hline $\begin{array}{l}\text { H3: The relationship between capital } \\
\text { and risk taking is stronger for insurers }\end{array}$ & $\alpha_{4}>0$ & 0.00 & 0.00 & 0.00 \\
\hline $\begin{array}{l}\text { H4: Stock insurers take more } \\
\text { investment risk than mutual insurers }\end{array}$ & $\alpha_{6}>0$ & 0.01 & 0.00 & 0.00 \\
\hline
\end{tabular}


Note: mean $\left(L O B_{q}\right)$ equals the sample mean of line of business dummy $q$.

${ }^{1}$ The supporting parameter values of $\alpha_{7}-\alpha_{10}$ are based on Table 1 .

${ }^{2}$ The difference in the equity allocations of pension funds and insurers is equal to the sum of $\alpha_{3}$ and coefficients $\alpha_{6}-\alpha_{13}$ (weighted by the sample means of the respective dummies).

\subsection{Equity allocations over time}

As Figure 1 in Section 3.2 shows graphically, the (weighted) average equity allocations are quite volatile over time. The question we try to answer here is to what extent this volatility is driven by investment behaviour and whether this behaviour can be related to our hypotheses on risk bearing capacity and risk taking incentives. Table 5 provides OLS and Weighted Least Squares (WLS) estimation results of Equation (4). The WLS estimations weight the changes in equity ratios with real equity holdings, thereby providing insight into possible behavioural differences between small and large equity investors. The first four columns present the results for pension funds, while the last four columns present the results for (both life and non-life) insurers.

Table 5. Equity trading model, estimation results, pension funds vs. insurers (2000-2009)

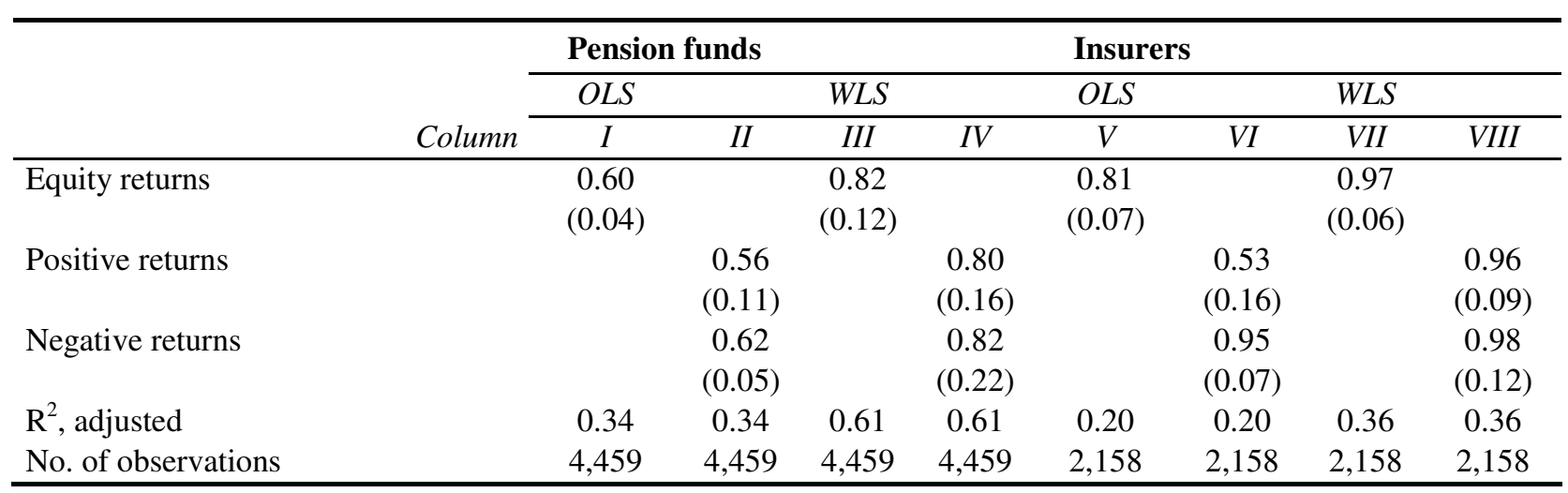

Notes: Robust Huber-White standard errors are in parentheses. The dependent variable in these regressions is the change in total equity holdings divided by year-end total investments. Only investors holding equities in their portfolio, either at the beginning or the end of the book year, are included in these regression analyses. The WLS estimation uses real equity holdings (in 2009 prices) as weighting factor.

Several findings stand out. First, Column $I$ and $I I$ show that pension funds rebalance, on average, $40 \%$ of market price movements (in line with Bikker et al. 2010) and that rebalancing is more or less symmetric in terms of positive versus negative returns. The coefficients 0.56 and 0.62 in Column II represent free-floating behaviour of around $60 \%$, which is the complement of rebalancing. Second, insurers tend to rebalance $50 \%$ of market price movements in bull markets, yet let their equity allocation fall in bear markets (column $V I$ ). Since negative feedback trading (or rebalancing) increases an investor's risk profile compared to a free-float strategy, these trading results provide further support to hypotheses $H 2$ (insurers take less investment risk) and $H 3$ (insurers are more risk sensitive in their investment behaviour). Indeed, insurers moderate their risk taking when returns are negative and their risk bearing capacity is down. Third, the WLS results in columns $I I I$ and $I V$ indicate that large pension funds generally rebalance less than their smaller peers. This finding over 2000-2009 contrast with what has been found in earlier research on the investment behaviour of Dutch pension funds by Bikker 
et al. (2010) over the 1999-2006 period. Though Bikker et al. (2010) use quarterly data, and we have annual observations, the frequency difference does not seem to drive our results. Indeed, we can replicate the results of this earlier study by taking approximately the same sample period (i.e. 20002006). ${ }^{18}$ Hence, the results indicate that large pension funds where unable to rebalance their sizeable equity losses of 2008 to the extent that they have done that before. Large pension funds' press statements dating from early 2009 are consistent with this interpretation. ${ }^{19}$ Our new finding is interesting from a macro-perspective, since pension funds are typically perceived as providers of risk bearing capital when it is most needed, yet did not perform this role at the height of the great financial crisis. Notice that the adjusted $\mathrm{R}^{2}$ statistics of the WLS regressions are much larger than those of the OLS regressions, indicating that market returns are a much better predictor of equity portfolio changes of large funds than those of small funds. Hence, there is less noise in the investment behaviour of large pension funds. The fourth and final finding from Table 5 is that large insurers pursue a completely free-float investment strategy, whether markets are up or down, where smaller insurers rebalance under favourable market conditions. Columns VII and VIII show that the estimated slope coefficients are not significantly different from 1 , indicating that, on average, equity price movements feed roughly one-to-one into the equity allocation.

To investigate trading behaviour across organizational form in the insurance industry, Table 6 shows estimation results of Equation (4) for stock and mutual insurers separately. The point estimates suggest that stock insurers rebalance slightly more than mutual insurers, yet the differences are at best marginally significant. So, while we have found that the level of risk taking by stock insurers is larger than that of mutual insurers, investment behaviour over time is not materially different. Both stocks and mutuals seem to pursue a free-floating strategy, at least on average.

Table 6. Equity trading model, OLS estimation results, stock vs. mutual insurers (1995-2009)

\begin{tabular}{lcccc}
\hline & \multicolumn{2}{c}{ Stock insurers } & \multicolumn{2}{c}{ Mutual insurers } \\
\cline { 2 - 5 } \multicolumn{1}{c}{ Column } & $I$ & $I I$ & $I I I$ & $I V$ \\
\hline Equity returns & 0.85 & & 0.94 & \\
& $(0.07)$ & & $(0.05)$ & 0.82 \\
Positive returns & & 0.79 & & $(0.16)$ \\
& & $(0.14)$ & & 1.06 \\
Negative returns & & 0.90 & & $(0.04)$ \\
& & $(0.09)$ & 0.40 & 0.40 \\
$\mathrm{R}^{2}$, adjusted & 0.19 & 0.19 & 1,066 & 1,066 \\
No. of observations & 2,250 & 2,250 & & \\
\hline
\end{tabular}

Note: See the notes below Table 5 .

\footnotetext{
${ }^{18}$ These results are not shown but available on request.

${ }^{19}$ Reuters, 'Losses prompt Dutch pension funds to cut equity risk', 30 January 2009.
} 


\section{Conclusion}

This paper examines the investment behaviour of Dutch pension funds and insurance firms from a risk perspective. We investigate which institutional investors take more investment risk and try to understand why this is the case. Two measures of investment risk taking are used. The first measure is the allocation of equities in the total investment portfolio, which is an intuitive and widely used. Our second measure concerns equity feedback trading. While there is a sizeable literature on feedback trading, the micro-prudential risk implications of such behaviour have typically been passed over. It is clear, however, that buying equities when equities are down (i.e. negative feedback trading, or rebalancing) is a risky strategy, since the exposure to equities is raised when risk bearing capacity is down. Under the same logic, positive feedback or momentum trading is risky in upward markets.

Using annual investments data over 1995-2009, we draw four clear conclusions about investment risk taking. First, pension funds take on board significantly more investment risk than insurers. A comparison of equity allocations shows that, corrected for capital and size, pension funds allocate a significantly larger fraction of their assets to equities. But also over the equity cycle, pension funds are more risk tolerant. Pension funds rebalance, on average, about $40 \%$ of market price movements, in both bull and bear markets. Insurance firms also rebalance in bull markets but do not buy equities in bear markets to restore their equity allocation. This finding confirms that, in bear markets when risk bearing capacity of insurers has been eroded, they are more risk averse. While insurance firms face direct and indirect costs of financial distress, pension funds do not face bankruptcy risk under detrimental market conditions. Even so, unfavourable investment results do hit pension fund participants, just as they benefit from favourable outcomes. It is the responsibility of pension funds to adequately inform their participants about the consequences of investment risk taking on the safety of pension benefits.

Second, and in line with expectations, we find that investors with higher risk bearing capacity take more risk than others. This conclusion is in line with the risk management hypothesis and is supported by many estimated parameters: institutions with higher capital buffers or funding ratios, more reinsurance and less underwriting risk, and pension funds with higher human and financial wealth per participant all invest more in equity. Size is also a significant driver of investment risk taking, though the effect is considerably smaller for insurers. As diversification benefits are expected to diminish with size, large pension funds appear to be more risk tolerant. 
Third, the relationship between risk bearing capacity and risk taking is found to be stronger for insurers than for pension funds. Apparently, insurers do not only take less investment risk than pension funds, they are also more risk sensitive in their investment behaviour. This greater risk sensitivity of insurers can once more be traced back to financial distress costs, but also to regulatory differences. When an insurer's capital ratio falls below the regulatory minimum, the prudential supervisor assumes control over the insurer. As a result consumers are protected against extensive losses and owners and management have an incentive to stay away from the regulatory minimum. When a pension fund falls below the minimal capital ratio of 5\%, however, it is given years to recover.

Our fourth conclusion is that stock insurance firms have more risky investments than their mutual peers, confirming the ownership-structure hypothesis. Over they equity cycle, however, stocks and mutuals do not behave materially different. Both types of insurers behave prudently in downturns, letting their equity allocations fall with their risk buffers.

\section{References}

Badrinath, S.G., Wahal, S, 2002, Momentum trading by institutions, Journal of Finance 57, 24492478.

Balvers, R., Wu, Y., Gilliland, E., 2000, Mean reversion across national stock markets and parametric contrarian investment strategies, Journal of Finance 55, 745-772.

Bikker, J,A., Vlaar, P.J.G., 2007, Conditional indexation of defined benefit pension plans, Geneva Papers on Risk and Insurance - Issues and Practice 32, 494-515.

Bikker, J.A., Broeders, D.W.G.A., De Dreu, J., 2010, Stock market performance and pension fund investment policy: rebalancing, free float, or market timing?, International Journal of Central Banking 6, 53-79.

Bikker, J.A., Gorter, J., 2011, Restructuring of the Dutch non-life insurance industry: consolidation, organizational form and focus, Journal of Risk and Insurance (forthcoming).

Bikker, J.A., Broeders, D., Hollanders, D., Ponds, E., 2011, Pension funds' asset allocation and participant age: a test of the life-cycle model, Journal of Risk and Insurance (forthcoming).

Black, F., 1988. An equilibrium model of the crash, NBER Chapters, in: NBER Macroeconomics Annual 1988, Volume 3, 269-276.

Broeders, D.W.G.A., Chen, A., Koos, B., 2011, An institutional evaluation of pension funds and life insurance companies, Insurance: Mathematics and Economics (forthcoming).

Brunnermeier, M.K., 2009, Deciphering the liquidity and credit crunch, Journal of Economic Perspectives 23, 77-100.

Committee of European Insurance and Occupational Pensions Supervisors (CEIOPS), 2008. CEIOPS' report on its fourth Quantitative Impact Study (QIS4) for Solvency II. Frankfurt am Main. 
Cohn, R.A. Lewellen, W.G., Lease, R.C. Schlarbaum, G.G., 1975, Individual investor risk aversion and investment portfolio composition, Journal of Finance 30, 605-620.

Cummins, J.D., Danzon, P.M., 1997, Price, financial quality and capital flows in insurance markets, Journal of Financial Intermediation 6, 3-38.

Cummins, J.D., Nini, G.P., 2002, Optimal capital utilization by financial firms: evidence from the property-liability insurance industry, Journal of Financial Services Research 21, 15-53.

Davis, E.P., 2002, Prudent person rules or quantitative restrictions? The regulation of long term institutional investors' portfolios, Journal of Pensions Economics and Finance 1, 157-191.

Esty, B.C., 1997, Organizational form and risk taking in the savings and loan industry, Journal of Financial Economics 44, 25-55.

Fama, E.F., Jensen, M.C., 1983, Agency problems and residual claims, Journal of Law and Economics 26, 327-349.

Gatzert, N., Schmeiser, H., 2008, Combining fair pricing and capital requirements for non-life insurance companies, Journal of Banking and Finance 32, 2589-2596.

Gompers, P.A., Metrick, A., 2001, Institutional investors and equity prices, Quarterly Journal of Economics 116, 229-259.

Grinblatt, M., Titman, S., Wermers, R., 1995, Momentum investment strategies, portfolio performance, and herding: a study of mutual fund behaviour, American Economic Review 85, 1088-1105.

Guo, D., Winter, R.A., 1997. The capital structure of insurers: theory and evidence. Working Paper, Sauder School of Business.

Haan, L. De, Kakes, J., 2010, Are non-risk based capital requirements for insurance companies binding?, Journal of Banking and Finance 34, 1618-1627.

Haan, L. De, Kakes, J., 2011, Momentum or contrarian investment strategies: evidence from Dutch institutional investors, Journal of Banking and Finance (forthcoming).

Jensen, M.C., Meckling, W.H., 1976, Theory of the firm: managerial behavior, agency costs and ownership structure, Journal of Financial Economics 3, 305-360.

Kakes, J., 2008, Pensions in a perfect storm: financial behaviour of Dutch pension funds (2002-2005), Applied Financial Economics Letters 4, 29-33.

Lakonishok, J., Schleifer, A., Vishny, R.W., 1992, The impact of institutional trading on stock prices, Journal of Financial Economics 32, 23-43.

Lamm-Tenant, J., Starks, L.T., 1993, Stock versus mutual ownership structures: the risk implications, Journal of Business 66, 29-46.

Lee, S.J., Mayers, D., Smith Jr., C.W., 1997, Guarantee funds and risk taking: evidence from the insurance industry, Journal of Financial Economics 44, 3-24.

Lucas, D.J., Zeldes, S.P., 2009, How should public pension plans invest? American Economic Review: Papers \& Proceedings 99, 527-532. 
Mayers, D., Smith Jr., C.W., 1987, Corporate insurance and the underinvestment problem, Journal of Risk and Insurance 54, 45-54.

Mayers, D., Smith Jr., C.W., 1992, Executive compensation in the life insurance industry, Journal of Business 65, 51-74.

Mayers, D., Smith Jr., C.W., 1994, Managerial discretion, regulation and stock insurer ownership structure, Journal of Risk and Insurance 61, 638-655.

Merton, R.C., Perold, A.F., 1998, Theory of risk capital in financial firms, in: J.M. Stern and D.H. Chew, Jr., Eds., The Revolution in Corporate Finance, Malden, MA: Blackwell Business, 266282.

Pástor, L.,Stambaugh, R.F., 2009, Are stocks really less volatile in the long run?, NBER Working Papers 14757, National Bureau of Economic Research, Inc. (or: CEPR Discussion Papers 7199, CEPR, London).

Rauh, J., 2009, Risk shifting versus risk management: investment policy in corporate pension plans, Review of Financial Studies 22, 2687-2733.

Shleifer, A., Vishny, R., 1992, Liquidation values and debt capacity: a market equilibrium approach, Journal of Finance 47, 1343-1366.

Smith, C., Stulz, R., 1985, The determinants of firms' hedging policies, Journal of Financial and Quantitative Analysis 20, 391-405.

Smith, B., Stutzer, M., 1990, Adverse selection, aggregate uncertainty and the role for mutual insurance contracts, Journal of Business 63, 493-511.

Sommer, D.W., 1996, The impact of firm risk on property-liability insurance prices, Journal of Risk and Insurance 63, 501-514.

Spierdijk, L., Bikker, J.A., Van der Hoek, P., 2010, Mean reversion in international stock markets: an empirical analysis of the $20^{\text {th }}$ century, DNB Working Paper nr. 247, De Nederlandsche Bank, Amsterdam.

Swiss Re, 1999, Are mutual insurers an endangered species?, Sigma, 4. 